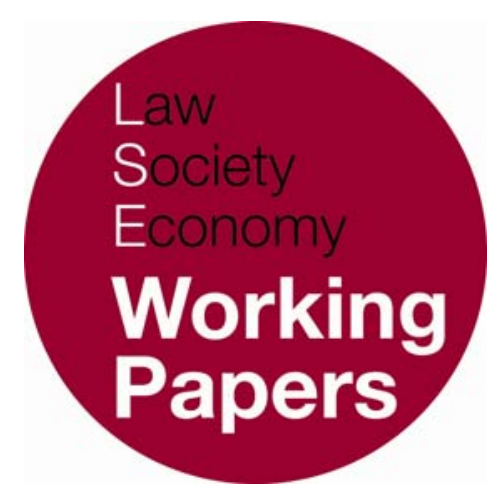

\title{
The Reformation of English Administrative Law
}

\author{
Thomas Poole
}

LSE Law, Society and Economy Working Papers 12/2007 London School of Economics and Political Science Law Department

This paper can be downloaded without charge from LSE Law, Society and Economy Working Papers at: www.lse.ac.uk/collections/law/wps/wps.htm and the Social Science Research Network electronic library at: http://ssrn.comabstract=1019001.

(C) Thomas Poole. Users may download and/or print one copy to facilitate their private study or for non-commercial research. Users may not engage in further distribution of this material or use it for any profit-making activities or any other form of commercial gain. 


\title{
The Reformation of English Administrative Law
}

\author{
Thomas Poole *
}

\begin{abstract}
This article examines the process of constitutionalisation that is ongoing in English administrative law. It does so by focussing on two key questions which, although hitherto largely overlooked by commentators, are beginning to receive attention in the courts. The first question - the 'sin' of omission - relates to the question of how the courts should respond when an agency has not consciously approached a decision through a rights-based framework. The second question - the 'sin' of commission - asks how courts should respond when an agency explicitly reaches a decision on the basis of rights and proportionality. The answers we give to these questions will help to define the nature of the emerging 'culture of rights'. Staking out a position against 'hardline' proponents of rights-based judicial review, I suggest, first, that agencies should not be placed under a duty to articulate decisions through a rights-based framework and, second, that some provisional weight should be accorded to an agency's own assessment of the rights issues at stake.
\end{abstract}

\section{INTRODUCTION}

Recent years have seen a reconfiguration in the discourse and norms of English judicial review. The terminology of Wednesbury unreasonableness and ultra vires seems on the verge of being superseded by the language of rights and proportionality. ${ }^{1}$ This metamorphosis has produced substantive changes: above all, a shift in emphasis from examining powers and procedures to the review of substance. But while some of the contours of the new conceptual framework are becoming clear, the relationship between courts and administrators that this new model entails has yet to be thought through. In particular, insufficient attention has been paid to the message sent by courts to administrators, and to how that message is translated from the language of the courts into that of the administrator.

This article examines this process of transformation and its consequences. The aim is to relate ongoing doctrinal discussions to contemporary structures of

\footnotetext{
* Law Department, LSE. I should like to thank Mark Aronson, Carol Harlow, Nico Krisch, Martin Loughlin and Richard Rawlings for their comments on an earlier draft.

${ }^{1}$ Cf N. Bamforth, 'Courts in a Multi-Layered Constitution' in N. Bamforth and P. Leyland (eds), Public Law in a Multi-Layered Constitution (Oxford: Hart, 2003).
} 
governance. $^{2}$ Two specific questions concerning the relationship between courts and agencies are addressed: first, whether courts should impose a general duty on public authorities to articulate their decisions in the language of rights and proportionality; second, whether courts should give any weight to public authorities' proportionality and rights-based assessments. The way we respond to these questions will do much to determine the kind of 'culture of rights' we expect the new order of administrative law to foster. ${ }^{3}$

\section{THE ‘CONSTITUTIONALISATION’ OF ADMINISTRATIVE LAW}

Dyzenhaus, Hunt and Taggart argued that we are experiencing an epochal moment within administrative law, ${ }^{4}$ central to which is the development of a general 'principle of legality'. ${ }^{5}$ This principle imposes 'both a duty on administrative decision-makers to give reasons for their decisions and a duty on judges to defer to those reasons to the extent that they refrain from reviewing on a correctness standard', and it functions 'as a constitutional principle, one that will in a sense constitutionalise administrative law.' While these observations are intended to apply to much of the common law world, the thesis has particular resonance in the domestic sphere, especially since the introduction of the Human Rights Act 1998. This new mode of 'constitutionalised' judicial review calls, the authors say, for a 'different methodology' which has at its heart the idea of instilling a 'culture of justification' within government and public administration: 'The notion of justification, as distinct from explanation, implies that the reasons supporting a decision be "good" reasons, and this in turn requires norms or rules for determining what counts as a "good reason"". 6 The substantive turn in

\footnotetext{
2 In doing so, I adopt a broad conception of administrative law as the body of law which 'establishes both primary rules governing how the administration is authorized to work (its organization, powers, and procedures), as well as the secondary rules governing remedies (judicial and other) available in cases of a failure to observe the primary rules.' J.S. Bell, 'Comparative Administrative Law' in M. Reimann and R. Zimmermann (eds), The Oxford Handbook of Comparative Law (Oxford: Oxford University Press, 2006) 1261.) See also, e.g., R.A. Stewart, 'Administrative Law in the Twenty-First Century' (2003) 78 New York University Law Review 437, 438: 'In liberal democratic societies, administrative regulation is itself regulated by administrative law. This law defines the structural position of administrative agencies within the governmental system, specifies the decisional procedures those agencies must follow, and determines the availability and scope of review of their actions by the independent judiciary. It furnishes common principles and procedures that cut horizontally across the many different substantive fields of administration and regulation.'

3 See, e.g., C. O'Cinneide, 'Democracy, Rights and the Constitution - New Directions in the Human Rights Era' (2004) Current Legal Problems 175, 187-188: 'the HRA [Human Rights Act 1998] not only enables courts to consider rights arguments, it also induces a "rights orientation" in how democratically derived powers are interpreted and applied.'

4 D. Dyzenhaus, M. Hunt and M. Taggart, "The Principle of Legality in Administrative Law: Internationalisation and Constitutionalisation' (2001) 1 Oxford University Commonwealth Law Journal 5.

${ }^{5}$ See, e.g., R v Secretary of State for the Home Department, ex p Simms [2000] 2 AC 115, at [131] (per Lord Hoffmann).

${ }^{6}$ See also D. Dyzenhaus, 'The Politics of Deference: Judicial Review and Democracy' in M. Taggart (ed.), The Province of Administrative Law (Oxford: Hart, 1997).
} 
administrative law undermines any pre-existing 'hard-and-fast distinction between process and substance' and generates a process of 'constitutional balancing' in which rights are weighed against the reasons offered in defence of governmental action that might be said to infringe them. International law also has an increased role within this new administrative law, since international legal norms both offer a 'good steer' as to the nature of the values that underpin the culture of justification and provide a 'powerful legitimating force'. ${ }^{7}$

Aspects of this analysis have been developed elsewhere. Taggart has argued that the new methodology outlined in the co-authored article is now 'firmly in place': administrative law in countries like the UK and New Zealand is 'in the throes of adjusting' to an enhanced role. The classic model is being reinvented, the emblematic move being the replacement of Wednesbury unreasonableness with the doctrine of proportionality. ${ }^{8}$ In place of review based ostensibly on ultra vires, ${ }^{9}$ courts now demand "justification of alleged rights-infringing behaviour and the adoption of a constitutional methodology of proportionality, balancing of rights and interests, and reasoned elaboration.' 10 This analysis (or prognosis) is supported by Hunt. Writing about contemporary British developments, Hunt argues that that Human Rights Act 'has potential to accelerate a long overdue reconfiguration of our public law around [the] important concept of justification, reconceiving our conceptions of law and legality away from formalistic concepts such as the historic will of Parliament, the separation of powers and ultra vires towards more substantive concepts of value and reason. ${ }^{11}$ Deepening the analysis in the context of an exploration of the relationship between administrative law and international law, Dyzenhaus suggests that the new 'common law of judicial review' involves 'a judicial updating of the common law's stock of values to include human rights', the articulation of which is not confined to domestic legal instruments. The 'human rights era' has produced a new system in which 'judges no longer consider their role to be guardians of values that sustain the relationship between citizen and state, but also, even primarily, guardians of the values that sustain the relationship between individual and state, in which the individual is understood as the bearer of human rights.' ${ }^{2}$ This 'tale of the evolution of the common law of judicial review' is not just a question of changes in judicial thinking, but also a matter of conceptual design. Dyzenhaus suggests, more specifically, that the separation of powers should be reconceived not as a formal

\footnotetext{
${ }^{7}$ See, e.g., K. Knop, 'Here and There: International Law in Domestic Courts' (2000) 32 New York Journal of International Law and Politics 501.

${ }^{8}$ See, e.g., R (Daly) v Secretary of State for the Home Department [2001] 2 AC 532. Cf Sir J. Laws, 'Wednesbury' in Forsyth and Hare (eds), The Golden Metwand and the Crooked Cord (Oxford: Clarendon Press, 1998) who suggests refashioning the old test as a 'rule of reason'.

${ }^{9}$ See D. Oliver, 'Is the Ultra Vires Rule the Basis of Judicial Review?' [1987] Public Law 543.

${ }^{10}$ M. Taggart, 'The Tub of Public Law' in D. Dyzenhaus (ed.), The Unity of Public Law (Oxford: Hart, 2004) 475 .

11 M. Hunt, 'Reshaping Constitutionalism' in J. Morison, K. McEvoy and G. Anthony (eds), Judges, Transition and Human Rights (Oxford: Oxford University Press, 2007) 470.

${ }^{12}$ D. Dyzenhaus, 'The Rule of (Administrative) Law in International Law' (2005) 68 Law and Contemporary Problems 127, 139.
} 
principle of institutional separation but as 'the realisation of, in Kantian terms, a republican ideal', a process that entails in its application that 'violations of the rule of law are to be determined by looking at the substantive values that the separation of powers are supposed to protect rather than to whether the particular arrangement of powers in a legal order has been disturbed.' ${ }^{13}$

This article accepts the central thrust of this constitutionalisation thesis. It works from the assumption that there has been a substantial reworking of the traditional English model of judicial review, ${ }^{14}$ a central feature of which has been a 'normative turn'15 and a concomitant shift in emphasis from procedural to substantive review. ${ }^{16}$ The primary doctrinal move in this development - for which the Human Rights Act was the catalyst - has been the adoption of the proportionality test and the (at least partial) abandonment of Wednesbury unreasonableness. ${ }^{17}$ Commentary on this development, both academic and judicial, has tended to revolve around the idea of 'deference': that is, the leeway or discretionary room for manoeuvre that the court grants a public authority on account of its expertise or authority. The development of notions of deference, as Hunt explains, can be seen as the flip-side of the courts' 'unequivocal embrace' of proportionality. ${ }^{18}$ In what follows, I address two questions which, as well as being central to the specification of the 'culture of rights', require us to consider the relationship between public authorities and the courts in this new context.

\section{PROBLEM 1: THE “SIN” OF OMISSION?}

The first problem, which I call the (putative) sin of omission, centres on the question of how the courts should respond when an agency has not consciously

\footnotetext{
13 ibid, 151-2.

14 See C. Harlow, 'A Special Relationship? American Influences on Judicial Review in England' in I. Loveland (ed.), A Special Relationship? American Influences on Public Law in the UK (Oxford: Clarendon Press, 1995) 83-86, which lists the features of the classic English model as: absence of any substantive distinction between public and private law; restricted grounds of review coupled wit a strict application of the doctrine of precedent; highly individualistic orientation and conspicuously marked by judicial restraint; interest-oriented, a fact reflected in the law of locus standi; remedy-oriented. See also M. Taggart, “"The Peculiarities of the English": Resisting the Public/Private Law Distinction' in P. Craig and R. Rawlings (eds.), Law and Administration in Europe (Oxford: Oxford University Press, 2003) 116-118.

${ }^{15}$ D. Dyzenhaus, 'The Politics of the Question of Constituent Power' in M. Loughlin and N. Walker (eds), The Paradox of Constitutionalism (Oxford: Oxford University Press, 2007) 135.

16 See, e.g., T.R. Hickman, 'The Reasonableness Principle: Reassessing its Place in the Public Sphere' (2004) 63 CLJ 166, 185-188.

${ }^{17}$ See, e.g., Daly, $\mathrm{n} 8$ above; The Association of British Civilian Interests - Far Eastern Division v Secretary of State for Defence [2003] EWCA Civ 473, [34] \& [35], where Dyson LJ remarked that it will not be long before someone steps up to perform the burial rites for Wednesbury. Cf $\mathrm{R}$ v Chief Constable of Sussex, ex $p$ International Trader's Ferry Ltd [1999] 2 AC 418 (where the House of Lords applied both proportionality and Wednesbury); M. Elliott, 'The Human Rights Act 1998 and the Standard of Substantive Review' [2002] Judicial Review 97.

${ }_{18}$ M. Hunt, 'Sovereignty's Blight: Why Contemporary Public Law Needs a Concept of "Due Deference"' in Bamforth and Leyland, n 1 above, 340-341. Hickman (n 16 above, 171-172) argues that Wednesbury unreasonableness and ultra vires 'were employed to conceal the development of administrative and public law in a cloak of moral neutrality'.
} 
approached the taking of the decision under review through a framework of rights. It addresses the question: do public authorities now have to look at all relevant decisions through 'the prism of the European Convention'? The issue was central in the Denbigh High School case. The case concerned the school's uniform requirement for girls. The policy, which was adopted after wide consultation, was designed to satisfy religious requirements. The claimant, Shabina Begum, believed that the shalwar kameeze (trousers and tunic) - which was permitted by the policy did not comply with the requirements of her religion, and insisted that she should be allowed to wear the jilbab (a full-length dress). The school refused to allow her to attend the school until she complied with the policy; Begum refused to attend unless she was allowed to wear the jilbab. The impasse was ended when she was accepted at a different school.

Overturning the first instance judgment, ${ }^{19}$ the Court of Appeal held that Begum's right to religious freedom under Article 9 ECHR had been violated. The School authorities had erred, it said, in failing to consider her case in an appropriately rights-responsive manner. More specifically, they had not applied a full-scale proportionality analysis of the case at hand, ${ }^{20}$ and for that reason the application should succeed. 'The School did not approach the matter in this way at all. Nobody who considered the issues on its behalf started from the premise that the claimant had a right which is recognised by English law, and that the onus lay on the School to justify its interference with that right'. ${ }^{21}$ Note that the judgment said nothing about whether as a matter of substance the School's decision to exclude Begum was justified; it relates solely to the decision-making process the School had followed when deciding Begum's situation. ${ }^{22}$ Nothing in this judgment should be taken as meaning that it would be impossible for the School to justify it stance if it were to reconsider its uniform policy in the light of this judgment'.23

The House of Lords allowed the school's appeal, the majority considering that there had been no interference with Begum's Art. 9 rights since the claimant and her family had chosen the school voluntarily and could, without undue difficulty, have gone to another school where she was allowed to wear a jilbab. ${ }^{24}$

${ }_{19}$ [2004] EWHC 1389 (Admin); [2004] ELR 374.

${ }_{20}$ R (SB) v Headteacher and Governors of Denbigh High School [2005] EWCA Civ 199; [2005] 2 All ER 396, at [75]: according to Brooke LJ, the structure of process of decision-making should have taken the following line: 'Has the claimant established that she has a relevant Convention right which qualified for protection under Art. 9(1)? (2) Subject to any justification that is established under Art. 9(2), has that Convention right been violated? (3) Was the interference with her Convention right prescribed by law in the Convention sense of that expression? (4) Did the interference have a legitimate aim? (5) What are the considerations that need to be balanced against each other when determining whether the interference was necessary in a democratic society for the purpose of achieving that aim? (6) Was the interference justified under Art. 9(2)?'.

$21 \mathrm{ibid}$, at [76] (per Brooke LJ). For critical analysis of this decision, see T. Poole, 'Of headscarves and heresies: the Denbigh High School case and public authority decision-making under the Human Rights Act' [2005] PL 685.

22 See also Re Conor [2004] NICA 45, at [28] \& [29].

${ }^{23} \mathrm{n} 20$ above, at [81]. See also Scott Baker LJ at [92].

${ }^{24}$ R (Begum) v Headteacher and Governor of Denbigh High School [2006] UKHL 15; [2006] 2 All ER 487, at [25] (per L Bingham), [50] (per L Hoffmann) and [87] (per L Scott). For analysis of the decision see D. McGoldrick, Human Rights and Religion: The Islamic Headscarf Debate in Europe (Oxford: Hart, 2006) 190-204. 
The issue of justification under Art. 9(2) was also considered, and the court held that the limitation on Begum's right to manifest her religion was justified. Lord Bingham criticised the procedural approach of the Court of Appeal to this question. The focus of decision-making under the HRA, he said, was not on whether a decision is the product of a defective process, but on whether the applicant's rights have been violated. Proportionality must be judged objectively by the court, and a proceduralist approach would introduce a new formalism into administrative practice. ${ }^{25}$ Lord Hoffmann's criticism was more direct: Article 9 is concerned with substance, not procedure and it confers no right to have a decision made in any particular way. "What matters is the result: was the right to manifest a religious belief restricted in a way which is not justified under article 9.2?' Public authorities - in this instance, headteachers and school governors - 'cannot be expected to make such decisions with textbooks on human rights law at their elbows.'26

The issue has been considered elsewhere. Kay $v$ Lambeth involved a number of appeals against dispossession orders issued by certain local authorities. In each of these cases, claimants had raised a defence on the basis that their occupancy was protect by the right to respect for the home guaranteed by Article 8 of the Convention. A central issue before the House of Lords was whether local authorities must prove in every case for dispossession that domestic law meets the requirements of Article 8. The House of Lords rejected this contention, their Lordships making it clear that local authorities should not be placed under an obligation in this context to make decisions through an ECHR prism. Lord Bingham said that, where a public authority seeks to evict a person from premises, 'that person must be given a fair opportunity to contend that the excepting conditions in article 8(2) have not been met on the facts of his case.' He did not accept, however, 'that the public authority must from the outset plead and prove that the possession order sought is justified. That would, in the overwhelming majority of cases, be burdensome and futile. It is enough for the public authority to assert its claim in accordance with domestic property law.'27 Lord Nicholls agreed, rejecting the claimant's proposal on the basis that it 'would be a recipe for a colossal waste of time and money'. Courts should proceed, he said, on the assumption that domestic law is compatible with Art. 8.28 Sensitivity towards the political context in which housing policy is made played a part in the decision. Lord Bingham observed that housing legislation strikes a balance between the competing claims to which scarcity gives rise, taking account, no doubt imperfectly but as well as may be, of the human, social and economic considerations involved.' The legal framework under which local authorities operate is therefore 'likely to satisfy the article $8(2)$ requirement of proportionality

$25 \mathrm{ibid}$, at [29-31].

$26 \mathrm{ibid}$, at [68].

${ }^{27}$ Kay $\mathrm{v}$ London Borough of Lambeth [2006] UKHL 10, at [29].

$28 \mathrm{ibid}$, at [55]. 
if it is clear that the statutory scheme represents a democratic solution to the problems inherent in housing allocation.' 29

One reason why this issue will continue to arise, despite the House of Lords' ruling in Denbigh, is that there are some occasions when the imposition of an obligation to consider an issue in Convention rights-specific terms is justified. This is true of procedural rights: for instance, the 'due process' protections contained within Article 6 of the Convention. ${ }^{30}$ But even in relation to other Convention rights, we would sometimes expect the decision-maker to bring its mind to bear on the rights-related questions at issue. Consider, for example, deportation decisions. In $R$ (Razgar) v Secretary of State for the Home Department, Dyson LJ said that it was 'clearly correct' to say that the Home Secretary had to address, in the context of immigration control, specific questions relating to the possible violation of ECHR rights: '(a) to what extent (if at all) is the ECHR right engaged by their removal; (b) what is the threshold of seriousness of harm; and (c) what is the appropriate level of risk of that harm occurring. These questions must be addressed by the Secretary of State when he considers whether to certify that an allegation of breach of human rights is manifestly unfounded' under the relevant section of the Immigration and Asylum Act 1999.31

Another reason why the 'sin of omission' question continues to arise goes deeper. Some see the emerging pattern differently from the House of Lords in its Denbigh and Kay $v$ Lambeth decisions. T.R.S. Allan has long regarded public law as a jurisprudence of rights. ${ }^{32}$ Turning his attention to recent doctrinal changes, Allan celebrates the coherence gained as a result of 'the gradual disappearance of rigid doctrinal barriers to judicial review' and deplores the new doctrine of judicial deference which threatens, he says, to play in adjudication under the HRA a similar role to that performed by justiciability in a previous era. While he accepts that, in some cases, courts should defer to decision-makers on democratic grounds, 'any search for an independent theory or doctrine of deference is almost certainly misguided.' 33 Murray Hunt's theory of 'due deference' is identified as an example of this (misguided) type. Although he doubts the value of 'spatial language of areas or margins of discretion', Hunt argues that a 'rich conception of legality and the rule of law' should accord 'a role for the democratic branches in the definition and furtherance of fundamental values.' 34 This position is anathema for Allan, who regards the task of articulating the nature and limits of the (new) constitutional order as pre-eminently a matter for the courts.

\footnotetext{
29 ibid, paras [33] \& [35] (per L Bingham).

${ }^{30}$ See, e.g., P. Craig, 'The Human Rights Act, Article 6 and Procedural Rights' [2003] PL 753.

${ }^{31} \mathrm{R}$ (Raagar) v Secretary of State for the Home Department [2003] EWCA Civ 840, [8].

32 See, e.g., T.R.S. Allan, 'Legislative Supremacy and the Rule of Law: Democracy and Constitutionalism' (1986) 44 CLJ 111; Allan, Constitutional Justice: A Liberal Theory of the Rule of Law (Oxford: Oxford University Press, 2001).

33 T.R.S. Allan, "Human Rights and Judicial Review: A Critique of "Due Deference" (2006) 65 CLJ 671, 671.

${ }^{34}$ M. Hunt, 'Sovereignty's Blight: Why Contemporary Public Law Needs a Concept of "Due Deference"' in N. Bamforth and P. Leyland (eds), Public Law in a Multi-Layered Constitution (Oxford: Hart, 2003) 339 \& 350.
} 
Another target of Allan's criticism is Laws LJ's judgment in International Transport Roth GmbH. In what amounts an attempt to create a framework for the calibration of deference, Laws LJ specified four principles for determining the level of deference owed by a court to a public authority. First, more deference should be shown an Act of Parliament than to a subordinate measure or executive decision. Second, there is more scope for deference "where the Convention itself requires a balance to be struck, much less so where the right is stated in terms which are unqualified'. Third, greater deference is owed where the subject-matter is within the constitutional responsibility of the decision-maker, and less when it lies within the constitutional responsibility of the courts. Fourth, the degree of deference also depends on whether the subject-matter lies within the expertise of the decision-maker or the court. ${ }^{35}$ Allan finds this and like approaches objectionable largely because he sees the very notion of deference as 'nonjusticiability dressed in pastel colours. ${ }^{36}$ Judicial deference, he says, is either an empty or a pernicious doctrine. It is empty if it 'purports to implement a separation of powers between the courts and other branches of government', since such a separation is secured by 'the proper application of legal principles defining he scope of individual rights'. It is pernicious if 'it permits the abdication of judicial responsibility in favour of reliance on the good faith or good sense or special expertise of public officials, whose judgments about the implications of rights in specific cases may well be wrong. ${ }^{37}$ Thus, a judge who allows her own view of a case to be displaced by the contrary view of public officials should be considered to have 'forfeit[ed] the neutrality that underpins the legitimacy of constitutional adjudication.' ${ }^{38}$ Considerations not directly related to the right in question - for instance, those that relate to 'characteristics of the decision-maker or its procedures' - are classified as 'external considerations' inappropriate for judicial consideration:

The only proper question for the court to consider is simply whether or not the decision falls within the sphere of decision-making autonomy that the claimant's right, on its correct interpretation, allows. The relative expertise of the decision-maker and the excellence of its procedures are relevant insofar as they generate convincing arguments - good reasons for curtailing rights grounded in reasonable policies and supported by clear evidence. The court must be persuaded by the reasons, however, rather than impressed by expertise or procedural competence. ${ }^{39}$

35 International Transport Roth GmbH v Secretary of State for the Home Department [2002] EWCA Civ 158; [2003] QB 728, at [81]-[87]

36 n 33 above, 682 .

37 ibid, 675 .

38 ibid, 676.

39 ibid, 671-72. 
Elements of Allan's rights-centred conception of administrative law find support elsewhere. ${ }^{40}$ Jeffrey Jowell also believes we have entered a new constitutional era in which the system of 'administrative review' suited to the old order has been replaced by a 'higher-order framework', constituted by the HRA, which 'constrains all public institutions' including Parliament and over which the proportionality test reigns. ${ }^{41}$ Like Allan, Jowell argues that ideas of deference must mutate to fit this new constitutional framework. He argues that it is no longer appropriate for courts to defer on grounds of constitutional competence, which relates to the authority of the body to decide the relevant question. (Although, unlike Allan, he does think that it is generally appropriate for the court to defer on grounds of institutional competence, which refers to the capacity of a body to make the relevant decisions. ${ }^{42}$ ) David Beatty celebrates, with Allan, the fluid and antiformalist character of 'new-style' judicial review. His book The Ultimate Rule of Law is a paean to the proportionality principle, which is identified as the centrepiece of the new constitutional law. Proportionality accounts, he says, for 'virtually every case in which courts have responded politically to protect people's general welfare and well being. ${ }^{43}$ In an argument intended to have general application, he proposes the unencumbered use of the proportionality principle by courts. 'Prudential arguments' calling for courts to defer to the expertise of officials are to be rejected: proportionality is the 'only conceptual apparatus judges have, and all that they need, to harmonize the autonomy of each person with the general will of the community'. ${ }^{44}$ Indeed, in his understanding of the subjective nature of rights and his willingness to shut out 'external' (non-rights based) elements from judicial consideration, Beatty goes further than Allan. His extreme position culminates in the (ludicrous) claim: 'Rather than evaluate the competing interests at stake against some external, objective standard or principle, judges try to assess the affected parties' own understanding of how significant the law being tested is for them.' 45

How might advocates of this forthright, highly juridified approach to creating a culture of rights-based justification respond to the question posed at the start of this section: how should a court respond when an agency has not consciously approached the issue at hand through an 'ECHR prism'? This specific question is addressed in their work, I believe, but it is plausible to assume that at least some of them would favour the imposition of a general duty on public authorities to approach relevant decision-making through a Convention framework. This position would be consistent with the arguments of Allan and Beatty. ${ }^{46}$ If creating

${ }^{40}$ See also, e.g., D. Dyzenhaus, 'The Politics of Deference: Judicial Review and Democracy' in Taggart, $n$ 6 above.

${ }^{41}$ J. Jowell, 'Judicial Deference and Human Rights: A Question of Competence' in Craig and Rawlings, Law and Administration in Europe, $\mathrm{n} 14$ above, 68.

42 ibid, 73.

${ }^{43}$ D. Beatty, The Ultimate Rule of Law (Oxford: Oxford University Press, 2004) 144.

44 ibid, 116.

45 ibid, 93.

46 Although, in fairness, it must be accepted that the hardliners' approach might be read rather differently: as an argument in favour of substantive as opposed to procedural justice. This reading of their position might well generate a different answer to this first problem - courts should not impose a general duty on 
a culture of justification is the central objective, then requiring public authorities to justify their decisions explicitly in terms of rights and related values is justified. Only by requiring public authorities to express themselves throughout the decision-making process in rights-based terms can we ensure that a rightsrespecting culture develops. Silence on the question of rights denotes a failure to do what a good decision-maker is required to do: consider the implications of its decisions in terms of the rights upon which they may impact.

This approach should be rejected. To require all relevant decisions to be made in Convention-friendly language would lead to the (short-term) ossification of public administration. Decision-makers across the spectrum of public administration would be forced both to rethink isolated decisions and to recast general decision-making strategies to ensure that they are at least couched in the language of rights and proportionality. Somewhat paradoxically given the hardliners' antagonism towards legal dogmatism, this approach also entails a deeply unattractive jurisprudence that is both intrusive and formalist. It would require courts to strike down decisions on purely procedural (or 'box-ticking') grounds - like the Court of Appeal in Denbigh - even where the right in question was transparently weak and the possible interference minimal. ${ }^{47}$

Projecting into the longer term, creating a general duty on public authorities to couch decisions in Convention-friendly terms would be to establish rights and proportionality as the lingua franca of public administration. But this vision of the future is to be avoided. Public authorities work in a variety of structures and frameworks and through a range of discourses. We may live in an 'age of rights', but we also seen profound changes in the configuration of the state and in the way in which public services are provided. The implications for administrative law of the collapse of the post-World War II social and economic consensus ${ }^{48}$ have been extensively charted and analysed. ${ }^{49}$ The extensive reorganisation of the machinery of the state led to the shattering of the public/private divide 50 and induced a conceptual shift from 'government' to 'governance'. ${ }^{51}$ This refashioning of what used to be called the public sector is recognised in the HRA: 'public authority' is used in section 6(3) of the Act to include any person or body 'certain of whose functions are functions of a public nature'. ${ }^{52}$ Change at the level of discourse has

public authorities to make decisions consciously and explicitly on the basis of Convention rights as that would deflect the 'rights revolution' from its proper substantive/normative orientation towards a uncalled-for focus on formalities and procedure.

47 Proceduralist decisions of this sort might also lead to confused confusion among both administrators and the broader public. The Court of Appeal decision in Denbigh was widely misperceived as being about substantive violations of rights. See, e.g., 'Muslim pupil wins religious dress ruling', The Guardian, March 2, 2005; 'School girl wins right to wear Muslim gown', The Telegraph, March 3, 2005.

48 See, e.g., D. Marquand (ed.), The Ideas that Shaped Modern Britain (London: Fontana, 1996).

49 See, e.g., I. Harden, N. Lewis and C. Graham, The Contracting State (Buckingham: Open University Press, 1992).

50 See, e.g., D. Oliver, Common Values and the Public-Private Divide (London: Butterworths, 2000)

51 See, e.g., R.A.W. Rhodes, 'The New Governance: Governing without Government' (1996) 44 Political

Studies 652; B.G. Peters and J. Pierre, 'Governance without Government? Rethinking Public Administration' (1998) 8 Journal of Public Administration Research and Theory 223.

52 See, e.g., D. Oliver, 'Functions of a Public Nature under the Human Rights Act' [2004] PL 329. 
been as far-reaching. Talk of 'risk' 53 and 'risk management' 54 has been layered over the discourse that drove public service reform in the 1980s and 1990s in which the 'three Es' of efficiency, economy and effectiveness were watchwords. 55

These shifting patterns within 'public administration' - no doubt a consequence of 'our tendency to hedge our bets in matters of governance'56 have produced a polyglot patchwork of decision-making institutions and players. In a recent attempt at mapping this complex scene, Colin Scott identifies four governance 'regimes' ${ }^{57}$ Governance through public law derived from the traditional 'state-centric conception of regulatory governance' in which control 'is often premised upon the use of law to make rules or standards'. ${ }^{58}$ Governance through markets and competition is 'premised upon the idea that the behaviour of dispersed buyers and sellers, when aggregated, creates a discipline on all actors in the market'. ${ }^{59}$ Unlike governance through public law, one attraction of markets in public management reform is the tendency to remove certain responsibilities from governments. Governance through networks and communities exploits the capacities of communities to develop social norms and to police them through non-coercive mechanisms. Governance through design refers to the construction of systems in response to which, when they are operating properly, 'there is nothing the object of regulation can do to change the way these modalities are applied.' 60 The aim of this form of control is 'to secure [a] pattern of behaviour by designing out any options of non-conforming behaviour', ${ }^{61}$ and thus seems to involve the denial of

53 See, e.g., U. Beck, Risk Society (London: Sage, 1992); M. Douglas and A. Wildavsky, Risk and Culture (Berkeley: University of California Press, 1983). Unlike the language of rights which are focused on the present (and recent past) and at least ostensibly aimed at protecting individual agency, risk brings with it (a) probability or speculation - future orientation, along particular lines (b) a kind of double fatalism, both in terms of an obsession with hazards and an implicit denial of the importance of human agency. The fatalistic note to discourses of risk might be connected with what some commentators refer to as a new 'politics of fear': see, e.g., C. Robin, Fear: The History of a Political Idea (Oxford: Oxford University Press, 2004); F. Furedi, Politics of Fear (London: Continuum, 2005).

54 J. Black, 'The Emergence of Risk-Based Regulation and the New Public Management in the United Kingdom' [2005] PL 512, 512: risk 'is fast becoming the central organising principle in regulation and public service delivery'. Examples include the Hampton Report (Philip Hampton, Reducing Administrative Burdens: Effective Inspection and Enforcement, Final Report (London, 2005)) and the Better Regulation Executive (Better Regulation Task Force, Alternatives to State Regulation (London, 2000)). On the implications of the new risk culture on administrative law, see E. Fisher, 'The Rise of the Risk Commonwealth and the Challenge to Administrative Law' [2003] PL 455.

55 See, e.g., C. Harlow and R. Rawlings, Law and Administration (London: Butterworths, 2nd ed, 1997), ch 5; C. Hood, 'A Public Management for All Seasons' (1991) 69 Public Admin. 3.

${ }_{56}$ Richard B. Stewart, 'Administrative Law in the Twenty-First Century' (2003) 78 New York University Law Review 437, 446.

57 ibid, provides a parallel account in which five distinct models or approaches within American administrative law are identified: (1) the common law model; (2) the traditional model; (3) the New Deal model of regulatory management; (4) the Interest Representation model; (5) analytic (or cost-benefit) management of regulation. He also notes the rise of two new regulatory techniques: governmentstakeholder networks (e.g. the OMC within the EU) and economic incentive systems (e.g. carbon trading).

58 C. Scott, 'Spontaneous Accountability' in M. Dowdle (ed.), Public Accountability: Designs, Dilemmas and Experiences (Cambridge: Cambridge University Press, 2006) 177-178.

59 ibid, 178.

60 ibid, 182.

${ }^{61}$ R. Brownsword, 'Code, Control, and Choice: Why East is East and West is West' (2005) 25 Legal Studies 1. 
human agency for the objects of regulation. Scott's thesis is that 'each modality of control (with the exception of the fourth) brings with it an accountability template as a more or less spontaneous incidence of the control modality.' ${ }^{62}$

Those who would seek to impose a general duty on public authorities to approach decisions through an ECHR prism call in effect for the imposition of a uniform pattern on the complex structure of contemporary governance, a pattern in which legalistic human rights reasoning would become a primary 'benchmark'. In this new operative framework, other issues and concerns that might justifiably interest agencies (efficiency, policy delivery, risk assessment, innovation, redistributive justice, fairness to all, and so on) would be relegated. This solution may appeal to those who share the über-liberal dream of realising 'in Kantian terms, a republican ideal' of government under the moral law. ${ }^{63}$ It may also hold some intuitive appeal to lawyers brought up to prize order and coherence. But the aim of reducing the polyphony of contemporary public administration to a monodic plainchant led by the judges is misguided. Instead of following the Court of Appeal in Denbigh in regarding an omission on a public authority's part to think and speak in rights-based terms as tantamount to a 'sin' within the new order, we should try to be more ecumenical. The hardliners' approach, with its emphasis on procedure over substance, mistakes the nature of Convention rights ${ }^{64}$ and also ignores the complexities of modern administration. Of the governance regimes identified by Scott, only one - governance through public law - might reasonably accommodate rights discourse within its conceptual matrix. (And we might note that public law, at least in the sense that Scott uses it, ${ }^{65}$ cannot be entirely reduced to a system for the protection of human rights.) For the rest, a 'top-down' imposition by courts of a requirement on agencies across the board to become fluent in the language of Convention rights and proportionality would amount to a straightjacketing of public administrators. Unless all discourses of governance other than through rights are now to be regarded as normatively lacking, the only conclusion is for courts to refuse to impose a general duty on public authorities to approach their decisions through an ECHR prism.

\section{PROBLEM 2: THE "SIN" OF COMMISSION?}

The second question is, in a sense, the opposite of the first. It asks: how should courts respond when a public authority consciously and explicitly comes to a

62 'Spontaneous Accountability', n 58 above, 183. n 56 above, 446, concludes in similar vein: 'While each model thus has serious limitations as a solution to democracy deficit, together they can be viewed as complementary. Each tends to compensate for the normative limitations of the other. ... These checks and balances, as well as our tendency to hedge our bets in matters of governance, help explain why we continue to use both approaches.'

63 n 12 above.

${ }^{64}$ See, e.g., Begum, n 24 above, at [29]-[31] (per L Bingham).

${ }^{6}$ See further C. Scott, 'The "New Public Law"' in C. Willett (ed.), Public Sector Reform and the Citizen's Charter (London: Blackstone, 1996). 
conclusion about rights and proportionality? When a public authority has examined and reached a decision at least partly through a consideration of its impact on Convention rights, the reviewing court is faced with a choice: either it can ignore the authority's own assessment of rights and proportionality, or it can give some - at least provisional - weight to that assessment.

This issue - which I will call this problem the (putative) sin of commission - has also received attention in the cases. Much of the discussion to date has been conducted in the language of deference. ${ }^{66}$ The most elaborate analysis of this sort was Laws LJ's painstaking attempt in International Transport Roth to delineate general principles of deference, referred to in the previous section. ${ }^{67}$ The House of Lords has generally been more reticent. Lord Hoffmann, while noting the 'current popularity of the word 'deference' to describe the relationship between courts and other political bodies', did not think that 'its overtones of servility, or perhaps gracious concession, are appropriate to describe what is happening. ${ }^{\prime} 8$ These comments are echoed in the recent Report of the House of Lords in Huang $v$ Secretary of State for the Home Department, where the weighing of various factors was said to be not 'aptly described as deference' but rather the 'performance of the ordinary judicial task of weighing up the competing considerations on each side and according appropriate weight to the judgment of a person with responsibility for a given subject matter and access to special sources of knowledge and advice.' ${ }^{69}$

But remarks of this sort only scratch the surface of the 'sin of commission' question, since they relate more to questions of semantics than substance. (The position adopted by the House of Lords to the relevant authorities in its decisions in Rehman or Gillan, for instance, can only plausibly be described by the word 'deference' or a close synonym..$^{70}$ ) The substantive issue was explored in Belfast City Council v Miss Behavin' Limited, which involved a challenge to the Council's decision to prevent the claimants from opening a sex shop in an area of Belfast. The argument that the decision violated the claimants' Article 10 right to free expression was swiftly rejected. ${ }^{71}$ The House was divided, however, on the separate question of what weight should be accorded to the views of public authorities involved in making decisions which are alleged to infringe Convention rights. On one side, Lord Hoffmann sought to extend the scope of the postDenbigh orthodoxy:

${ }^{66}$ See, e.g., R v DPP, exp Kebilene [2002] 2 AC 326, 381B-D (per L Hope); A v Secretary of State for the Home Department [2004] UKHL 56; [2005] 2 AC 68, at [37-42] (per L Bingham).

${ }^{67}$ International Transport Roth GmbH v Secretary of State for the Home Department [2003] QB 728 at [767].

${ }^{68} \mathrm{R}$ (ProLife Alliance) v British Broadcasting Corporation [2004] 1 AC 185, at [75].

${ }^{69}$ Huang v Secretary of State for the Home Department [2007] UKHL 11, at [16].

70 Secretary of State for the Home Department v Rebman [2002] 1 All ER 122, at [62] (per L Hoffmann); R (Gillan) v Commissioner of Police for the Metropolis [2006] UKHL 12, in which the decision to accept (or defer to) the risk assessment of the Assistant Commissioner and the Home Secretary was described as 'not a question of deference but ... "relative institutional competence" (per L Bingham at [17]). See also the extra-judicial 'debate' between Lords Hoffmann and Steyn: L. Hoffmann, 'COMBAR Lecture 2001: Separation of Powers' [2002] Judicial Review 137; L. Steyn, 'Deference: A Tangled Story' [2005] PL 346.

71 [2007] UKHL 19, at [83]: 'Article 10 is indeed engaged in this case, albeit at a relatively low level' (per L Neuberger). 
A construction of the Human Rights Act which requires ordinary citizens in local government to produce such formulaic incantations would make it ridiculous. Either the refusal infringed the respondent's Convention rights or it did not. If it did, no display of human rights learning by the Belfast City Council would have made the decision lawful. If it did not, it would not matter if the councillors had never heard of article 10 or the First Protocol. ${ }^{72}$

Other members of the court adopted a different approach. Baroness Hale said that the court is 'bound to acknowledge' that the local authority is better placed to decide whether the right (in this case) to sell pornography should be restricted. But the respect that was due the authority depended on the way it had approached that question:

the views of the local authority are bound to carry less weight where the local authority has made no attempt to address that question. Had the Belfast City Council expressly set itself the task of balancing the rights of individuals to sell and buy pornographic literature and images against the interests of the wider community, a court would find it hard to upset the balance which the local authority had struck. ${ }^{73}$

Lord Neuberger agreed with Baroness Hale. When reaching a licensing decision of this sort, a local authority 'would be well advised', he said, to take the right to freedom of expression into account. While such an assessment 'cannot be conclusive', 'it seems to me consistent with what Lord Bingham and Lord Hoffmann said in Denbigh ... that where a council has properly considered the issue in relation to a particular application, the court is inherently less likely to conclude that the decision ultimately infringes the applicant's rights. ${ }^{74}$

We are presented, then, with a choice. One approach - represented by Lord Hoffmann in Miss Behavin' - regards the assessment by a public authority of rights and proportionality with complete indifference, since the decision as to whether a Convention right is infringed is exclusively a matter for the court. The other articulated most clearly by Baroness Hale in the same case - argues that the general approach of the court should be to show some measure of regard or respect for the way in which an authority handled rights-based concerns. There seem, at first glance, to be good arguments in favour of Lord Hoffmann's approach. Baroness Hale's solution, it might be said, would introduce into domestic administrative law a watered-down version of the American Chevron 'due deference' doctrine. ${ }^{75}$ That doctrine 'applies at federal level to cases where an

$72 \mathrm{ibid}$, at [13].

$73 \mathrm{ibid}$, at [37].

$74 \mathrm{ibid}$, at [91].

75 Cheuron USA Inc v Natural Resources Defense Council Inc 467 US 837 (1984) at 865-866: Judges are not experts in the field, and are not part of either political branch of the Government ... While agencies are not directly accountable to the people, the Chief Executive is, and it is entirely appropriate for this 
agency's Act or subordinate legislation is sufficiently unclear to admit of at least two interpretations, and where Congress can be taken to have delegated to the agency the task of filling in the statutory gaps with formal interpretive rulings'. In that situation, 'the court must defer to the agency's interpretation if that is formally promulgated, even if the net effect is to allow an agency interpretation to overturn an earlier and hitherto binding judicial interpretation'. ${ }^{76}$ By contrast, English courts have traditionally assumed that it was the duty of superior courts of general jurisdiction to ensure that public power is exercised according to law, an assumption which entailed that courts generally refused to accord any authoritative status, edge or weight to legal rulings from non-judicial officers. ${ }^{77}$ The analogy is not intended to be exact: the Chevron doctrine applies to vague terms of operative legislation, whereas our focus is on the constitutional or jurisprudential frame in which administrative action should take place.

But supporters of the Hoffmann approach might that the alternative would introduce an unwarranted deviation from English orthodoxy. Some commentators - particularly the 'hardliners' - might be suspicious of Baroness Hale's solution for a different (or additional) reason. We saw earlier that Allan rejects the very idea of judicial deference to agency assessments (of proportionality or anything else) on the basis that deference is 'non-justiciability dressed in pastel colours'. From this perspective, to follow Baroness Hale's approach would be to renege on the duty of the court to delineate the contours of the new constitutional politics centred on a culture of rights-based justification.

I want to assess these two solutions from a different standpoint. Assuming that the courts respond to the previous ('sin of omission') question by deciding not to impose a general duty on public authorities to approach their decisions through the ECHR prism - a reasonable assumption given the state of the authorities - then it may be that the hardliners' response to the 'sin of commission' question is ultimately self-defeating. On Lord Hoffmann's approach, the human rights calculations of public authorities are meaningless: an authority is equally damned whether it approaches a decision in Convention-specific terms or whether it does not. If the underlying goal is to encourage an administrative culture that is mindful of human rights, then this approach is counterproductive

political branch of the Government to make such policy choices - resolving the competing interests which Congress itself either inadvertently did not resolve, or intentionally left to be resolved by the agency charged with the administration of the statute in light of everyday realities.' Canada has a similar doctrine of judicial 'deference' to agency interpretations of 'their own' laws, although it rests on an acceptance of the 'administrative state' as a fourth branch of government, whose interpretative role carries some precedent force which is entitled to some (but not automatic) respect: Canadian Union of Public Employees, Local 963 v New Brunswick Liquor Corp [1979] 2 SCR 227; Baker v Canada (Minister of Citizenship and Immigration) (1999) 174 DLR (4th) 193.

76 M. Aronson, B. Dyer and M. Groves, Judicial Review of Administrative Action (Thomson, 4th ed, forthcoming). See also, e.g., John F. Duffy, ‘Administrative Common Law in Judicial Review' (1998) 77 Texas Law Review 113, 192: which says that 'Chevron rescues the Justices from lawmaking on a small scale and allows them to operate at the level where real power is' and argues that Chevron is 'primarily a case about delegation, not deference' (at 202). Cf Cass R. Sunstein, 'Law and Administration after Chevron' (1990) 90 Columbia Law Review 969, which regards Chevron as a 'counter-Marbury principle'.

77 See, e.g., Anisminic Ltd v Foreign Compensation Commission [1969] 2 AC 147. See also H. Woolf, 'Droit Public - English Style' [1995] PL 57, 67-69. 
since it removes any legal incentive for an authority to consider and articulate its decisions in rights-conscious terms.

The alternative solution, in which courts attach presumptive weight to an agency's human rights calculations, rejects the 'top-down', court-centred model proposed by Lord Hoffmann and favoured by the hardliners. Sometimes this approach may be justified by arguments relating to constitutional competence. As Lord Bingham expressed it in $R \mathrm{v}$ Lichniak - a case involving a challenge to the mandatory life sentence for murder under the Murder (Abolition of Death Penalty) Act 1965 - ' $[\mathrm{t}$ he fact that [the Act] represents the settled will of a democratic assembly is not a conclusive reason for upholding it, but a degree of deference is due to the judgment of a democratic assembly on how a particular social problem is best tackled.' ${ }^{78}$ It may sometimes be supported on grounds of what Jowell calls 'institutional competence': that the decision-maker under review, for reasons of capacity or expertise, is better placed than the court to consider the issues at stake. ${ }^{79}$ But perhaps the strongest argument in its favour is more pragmatic in nature and relates to the objective of developing a culture of rights. While this approach by no means precludes a hardening of the standard of review in suitable cases - in relation, say, to reviewing counter-terrorism laws ${ }^{80}$ - it creates a direct incentive for agencies to think through the ECHR prism, since decisions are less likely to be struck down by a court if they are articulated in rights-based terms. Not only would this create a space in which an agency could assume responsibility for the initial translation of rights discourse into the specific administrative context in which the agency operates. It would also take an agency's assessment of rights and proportionality seriously, thereby opening up the possibility of some sort of exchange - or 'dialogue' - on human rights matters between courts and administrators, ${ }^{81}$ an unlikely prospect if Lord Hoffmann's top-down model were preferred. Baroness Hale's approach should be favoured, then, mainly because it represents the best route towards inculcating a plausible culture of rights within the structures and pathways of governance. While some might mourn the loss of juridical control that is inherent to this solution, the watering down of legal control should be seen as the price to be paid for securing an administrative culture of rights-conscious justification.

\footnotetext{
78 R v Lichniak [2002] UKHL 47, at [14]. See also, e.g., Kay v Lambert, n 27 above, at [33] \& [35] (per L Bingham); R v Lambert [2001] 2 WLR 211, 219 (per L Woolf).

${ }^{79}$ See, e.g., R (Alconbury Developments Ltd) v Secretary of State for the Environment and the Regions [2001] 2 WLR 1389.

${ }^{80}$ See, e.g., A v Secretary of State for the Home Department [2004] UKHL 56; [2005] 2 WLR 87.

81 On the impact of the HRA see, e.g., S. Halliday and P. Schmidt (eds), Human Rights Brought Home: SocioLegal Perspectives on Human Rights in the National Legal Context (Oxford: Hart, 2004).
} 


\section{TOWARDS A CULTURE OF RIGHTS: BUT WHICH?}

This article has examined two questions, the answers to which will help determine the shape of the emerging 'culture of rights'. The first question asks whether a public authority's silence on the question of rights at the decision-making stage should itself count as a breach of the HRA-imposed duty not to infringe Convention rights. Some might be tempted to answer this question in the affirmative - certainly that was the approach of the Court of Appeal in Denbigh. Such an approach might find support in the theories presented by writers such as Allan and Beatty, who advocate a conception of constitutional politics in which the court is the central agent within a culture of rights-based justification. A public authority's silence on the question of rights might, from this perspective, be regarded as a failure to do what a good decision-maker is now required to do: namely, to articulate its decisions through a framework of Convention rights. I have argued that the House of Lords were right to reject this approach in Denbigh and Kay $v$ Lambert. Not only would the other approach lead to a formalist and proceduralist jurisprudence, it also fails to pay sufficient regard to the diverse reality of contemporary governance.

The second question asks whether the court should give provisional weight to an authority's own assessment of the rights issues at stake. This question divided the House of Lords in Miss Behavin'. Lord Hoffmann argued that no weight should be given to an authority's 'incantations' of human rights: 'no display of human rights learning' on the authority's part can make no difference to whether or not its decision infringed the Convention. By contrast, Baroness Hale and Lord Neuberger thought that where an authority has considered the human rights implications of its decision, then the court is 'inherently less likely to conclude that the decision ultimately infringes' Convention rights. The line charted by Lord Hoffmann is more likely to find favour with 'hardline' advocates of rights-based public law. Allan, for instance, argues that deference is tantamount to reneging on the judicial task of articulating the nature and limits of the new constitutional order. Non-rights related considerations are, for him, not properly matters for the court. This court-centred approach to creating a rights-based culture is ultimately self-defeating since, were it consistently applied, there would be no (legal) incentive for public authorities to examine decisions through an 'ECHR prism'. Baroness Hale's approach is preferable precisely because it provides such an incentive. Her solution also allows greater scope for public authorities to internalise human rights discourse within their own structures, and opens up the possibility of productive dialogue between courts and administrators on human rights matters.

Underneath these responses lie not only two different visions of rights in administrative law, but also two different visions of the role of rights in contemporary structures of governance. Both recognise that the discipline is undergoing profound change - the 'normative turn' identified by Dyzenhaus. But the hardliners present a vision of administrative law that has been effectively 
assimilated by human rights, while the other approach articulates a conception of administrative law that seeks to accommodate rights and the doctrines that relate to them within a wider conception of administrative justice. These different perspectives generate different understandings of the basic elements of the new order. While some hardliners might re-imagine due process requirements as centring on the duty to articulate one's decisions in rights-based terms, the alternative approach rejects such a course, arguing that the judicial assessment of procedural requirements remains inescapably contextual, ${ }^{82}$ and may or may not involve rights. And while hardliners tend to stigmatise considerations other than rights as 'external' to judicial decision-making, the alternative approach insists that (even in cases involving rights) the immediate political and administrative context surrounding impugned decisions remains vital for judicial consideration. ${ }^{83}$ More significantly, these two models also tell different stories about the process of juridification that necessarily accompanies the introduction of legally enforceable human rights. ${ }^{84}$ For the hardliners, the court stands at the heart of a system of rights-based constitutional politics and any public authority can in principle be called before the court to give an account of its decision-making in terms relating to the rule of law, understood in its 'thick' or value-laden sense. ${ }^{85}$ From this hub, principles of legality and equality are expected to radiate outwards (or downwards) across the range of public administration. Objecting to a court-dominated model that would turn the age of rights into an 'era of scholasticism' 86 in which public administrators are obliged to work their way through a legalistic maze, advocates of the other approach tend to be more empiricist in outlook and ecumenical in attitude. They suggest, that is to say, that the starting point for courts developing the new administrative law should be an awareness both of the difficulty of trying to situate rights within the multiplicity of existing governance structures and of the desirousness of taking seriously the agency's attempt to work out for itself what rights mean.

\footnotetext{
82 See, e.g., Bushell v Secretary of State for the Environment [1981] AC 75.

83 See also T. Poole, 'Legitimacy, Rights and Judicial Review' (2005) 25 OJLS 697.

${ }^{84}$ See M. Loughlin, The Idea of Public Law (Oxford: Oxford University Press, 2003) 131, in which juridification is defined is 'the tendency to conceptualize extensive spheres of public life in legal terms.' See also J. Habermas, The Theory of Communicative Action, Vol. 2 (Cambridge: Polity, trans. T. McCarthy, 1989).

${ }^{85}$ See, e.g., Constitutional Justice, n 32 above.

${ }^{86}$ M. Loughlin, 'Rights, Democracy, and Law' in T. Campbell, K.D. Ewing and A. Tomkins (eds), Sceptical Essays on Human Rights (Oxford: Oxford University Press, 2001), 59.
} 